\title{
Effect of environment on repetitive strain in grape cultivation
}

\section{SAVITA KUMARI AND MANJU MEHTA}

Article Chronicle : Received: 22.02.2017;

Revised : 02.05.2017; Accepted : 16.05.2017

Key Words : Grapes cultivation, Environmental parameters, ART, Strain index, $\mathrm{VO}_{2}$ $\max$
ABSTRACT : The aim of this study was to find out the effect of environment on repetitive strain in grape cultivation. The research designs comprised on field study conducted on 15 respondents were engaged on grapes cultivation activities. Physical fitness was determined by calculating the physiological parameters i.e. blood pressure, body temperature, pulse rate and maximum aerobic capacity $\left(\mathrm{VO}_{2}\right.$ max). Environmental parameters measured through repetitive strain exertion, ART tool and strain index. The results indicated that mean height and weight of grape workers involved in grape was $159.9 \mathrm{~cm}$ and $64.2 \mathrm{~kg}$, respectively. Body mass index (BMI) was observed as $21.8 \mathrm{~kg} / \mathrm{m}^{2}$. Fat percentage was worked out to be 29.9 per cent. Hence, LBM (Lean body mass) was $44.1 \mathrm{~kg}$ with variation of $\pm 19.3 \mathrm{~kg}$. Aerobic capacity $\left(\mathrm{VO}_{2} \max\right.$ ) was found to be $31.8 \mathrm{ml} / \mathrm{kg} . \times \min$ exhibiting that the subjects were having good health. Conclusively environmental parameters were directly affecting the health status of workers in terms $\mathrm{VO}_{2}$ max and BMI and (ART) and strain index. On the basis of total repetitive strains score in grape cultivation was maximum in pruning (239.5), followed by harvesting with total repetitive strain load (108.4).

HOW TO CITE THIS ARTICLE : Kumari, Savita and Mehta, Manju (2017). Effect of environment on repetitive strain in grape cultivation. Asian J. Environ. Sci., 12(1): 23-30, DOI: 10.15740/HAS/AJES/12.1/23-30.
Author for correspondence :

\section{SAVITA KUMARI}

Department of Family

Resource Management,

C.C.S. Haryana

Agricultural University, HISAR (HARYANA) INDIA

Email : jrozydhiman@

gmail.com

See end of the article for

Coopted authors' 